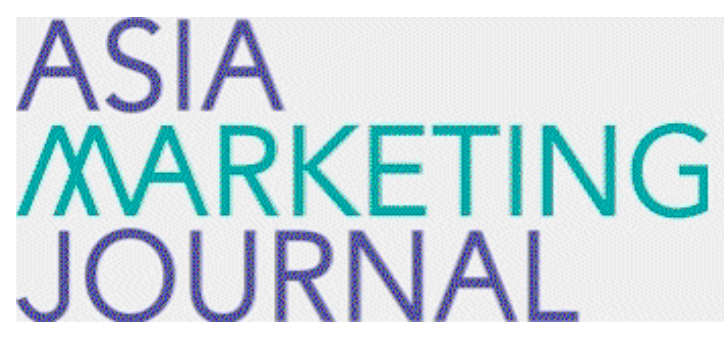

ASIA MARKETING JOURNAL

Volume 11 | Issue 2

Article 6

7-30-2009

\title{
The Role of Ethnocentrism and Firms Reputation of a Country of Origin on Consumer Purchase Intention
}

Nadia Jimenez

Sonia San Martin

Follow this and additional works at: https://amj.kma.re.kr/journal

Part of the Marketing Commons

\section{Recommended Citation}

Jimenez, Nadia and Martin, Sonia San (2009) "The Role of Ethnocentrism and Firms Reputation of a Country of Origin on Consumer Purchase Intention," Asia Marketing Journal: Vol. 11 : Iss. 2 , Article 6. Available at: https://doi.org/10.53728/2765-6500.1238

This Article is brought to you for free and open access by Asia Marketing Journal. It has been accepted for inclusion in Asia Marketing Journal by an authorized editor of Asia Marketing Journal. 


\title{
The Role of Ethnocentrism and Firms Reputation of a Country of Origin on Consumer Purchase Intention
}

\author{
Nadia Jiménez* \\ Sonia San Martín**
}

The growth of international trade and the formation of supranational economic and political trading blocks have noticeably widened the presence on the market of products of different national origins. This has stimulated interest in explaining the Country-of-Origin (COO) role in domestic and international markets and its consequences on consumer behaviour. Since the consumer purchasing decisions can be decisive to the success of a company's strategy in domestic and foreign markets, the objective of this study is to present empirical evidence on the extent to which reputation of firms associated to a certain $\mathrm{COO}$ are related to consumer purchase intention. Additionally our study considers ethnocentrism as a variable that partially explains the rejection of imports products based on its foreign origin. The empirical application of the proposed model is related to the purchase of Korean automobiles which represents $5.7 \%$ of the national market share in Spain. Structural equation modelling was used to analyse the data collected from 202 personal interviews carried out in a large Spanish region. The results show that reputation of firms associated to a certain $\mathrm{COO}$ in an important factor to establish business relationships involving consumers and firms from different countries and increase intentions to purchase Korean products. Additionally, ethnocentric consumers prefer to purchase domestic products rather than foreign imports as an attempt to protect national economy however the negative effect of ethnocentrism is weaker than positive effect of firms reputation of a COO.

Key words: firms reputation of a $\mathrm{COO}$, ethnocentrism, purchase intention, Korea, Spain, automobiles

\section{Introduction}

When a firm seeks to cultivate a new export market or expand its share of an existing market, it may well realize that it has been preceded by its reputation to sell or manufacture specific kinds of products. If the firm does not have a readily identifiable brand name, which is the case of manufacturers from newly

\footnotetext{
* School of Economics and Business Administration, University of Burgos (Spain).

** Professor and researcher in Marketing, School of Economics and Business Administration, University of Burgos (Spain).
} 
developing countries, the reputation of firms associated to a certain $\mathrm{COO}$ could play an important role predicting consumer behaviour related to the purchase of foreign products. The purpose of this study is to offer empirical evidence on the extent to which reputation of firms associated to a certain COO represents a quality signal associated with the firms from a country and how this signal can influence consumer purchase intention. Additionally our study contrast if consumer ethnocentrism explains the consumer purchase intention related to imports products. Thus, Vida and Reardon (2008) suggest that the speed with countries overcome economic problems depends on how fast firms and consumers adapt to new competitive circumstances in the market. This study is interesting in the actual situation of economic crisis which also affects automobile industry.

The main contributions of this research are the following:

1) A careful literature review reveals a lack of research about a concept linked to $\mathrm{COO}$ effect that works as a signal of quality. Our study tries to empirically test the consequences of the concept "reputation of firms associated to a certain $\mathrm{COO}$ "1) and proposes the application of the Signalling Theory, which has not been contemplated in previous $\mathrm{COO}$ literature where the more addressed approach is the Information
Processing Theory (Bilkey and Ness, 1982; Ozanne et al., 1992; Wright, 1975; Häubl, 1996: Vida and Reardon, 2008) that considers variables such as $\mathrm{COO}$ image (specified at the general country level) and country of design or country of manufacture (specified at the product level), but not a signal that reflects COO firms' prestige, reputation, capabilities and know-how.

2) Drawing on multidisciplinary concepts taken from marketing, psychology and sociology, this paper considers firms reputation of a COO and ethnocentrism, addressing how consumers deal with simultaneous positive and negative perceptions about products from a specific country (Otnes et al., 1997). To the best of our knowledge, previous literature have analyzed the effects of COO in purchase intention (Thorelli et al., 1989; Yaprak, 1978) and the influence of ethnocentrism on purchase intention (Verlegh, 2007; Nijssen and Douglas, 2004; Shimp and Sharma, 1987; Good and Huddleston, 1995), but this is the first study that analyzes the effects of positive (firms reputation of a $\mathrm{COO}$ ) and negative (ethnocentrism) variables on purchase intentions simultaneously (Balabanis y Diamantopoulos, 2004).

3) We analyse the effects of these two variables in a different context (Spain) and related to Korean automobiles which are gaining importance in this market. A carefully

1) The short name "firms reputation of a COO" will be used instead of "reputation of firms associated to a certain COO" to get a text simplification for reading. 
literature review show only one study related Spanish consumers ethnocentrism and not related to automobiles (Luque-Martínez et al., 2000). In contrast with the most majority of existing studies that has focused on well developed and established automobiles industries such as European and North American automobile industry (Moon and Jain, 2002; Balabanis and Diamantopoulos, 2004; Javalgi, 2005), our study contributes to assess the effect of ethnocentrism on Korean automobiles.

The paper is structured into four sections. Following this introduction, a review of the literature is presented in which the key variables are defined and the hypothesis stated. The research method is then explained and the results of the structural equation model are set out. Finally, the main conclusions and implications of the study are discussed. Reference is also made to its limitations and to future lines of research.

\section{Background}

\subsection{Conceptualization of firms reputation of a $\mathrm{COO}$}

Researchers examining $\mathrm{COO}$ effect have arrived at inconsistent findings due to the diverse backgrounds, conceptions and contexts involved in the analysis of this term. Some studies deal with the effects of $\mathrm{COO}$, others have focused on the relative influence of $\mathrm{COO}$ information versus other product attributes or have considered it as yet another cue (such as brand name, price and warranty) with which to evaluate product quality (Agrawal and Kamakura, 1999; Tan et al., 2001; Thorelli et al., 1989; Bilkey and Ness, 1982). There are, moreover, studies that define $\mathrm{COO}$ as one element of a brand that leads consumers to identify the firm with the $\mathrm{COO}$ domicile even if the product under evaluation was not manufactured there (Ahmed et al., 2004; Thakor and Kohli, 1996; Jin et al., 2006). COO has been considered as "country of manufacture", "country of assembly" and "country of design" (Han and Terpstra, 1988; Hamzaoui and Meruka, 2006; Ahmed and Astous, 1996; Bilkey and Nes, 1982; Klein et al., 1998). But in all cases, it has been perceived as a cue that is capable of summarising information on products, brands and firms from different countries.

Consumer preferences for products of a specific origin can be a consequence of diverse reasons: product dependency, COO image, similarities between countries, a country's level of development and/or consumers' beliefs, stereotypes and experiences (Cordell, 1992). Consumers hold to beliefs and perceptions about countries, which in turn influence their evaluations at the time of purchasing (Hamzaoui and Merunka, 2006; Tan et al., 2001). Agrawal 
and Kamakura (1999) establish that a product's objective quality varies within countries, and those differences are consistent with each consumer's perceptions of the product's origin.

In present context, companies distribute their goods to consumers all over the world and at the same time, consumers are able to choose from a broad range of products and services in almost any category. International product adaptation makes it difficult to differentiate between goods, and consumers find it more complicated and costly to obtain additional information on the quality of imports and on the behaviour of foreign firms. The existence of asymmetric information on products and firms in international markets causes uncertainty over the characteristics of the products for the less well informed part, in this case the consumer. When consumers find it difficult to distinguish between suppliers with different levels of quality in their products, they confront the problem known in agency theory as adverse selection (Singh and Sirdeshmukh, 2000). According to Amine and Shin (2002), a lack of country information will often blind a consumer to a product's real quality or attributes. This fact added to stereotypical information related to the origin of the products may condition consumer information processes and override previous negative information stored in the memory.

Signalling Theory can provide insight into the role of "firm reputation of a COO" as an instrument that a foreign firm can use to convey information on their quality and behaviour (Singh and Sirdeshmukh 2000). This approach can help us in our attempt to associate the underlying difficulties of purchasing foreign products and the relevance of $\mathrm{COO}$ to efficient decision making. Signalling Theory provides a framework to study the problem of consumer uncertainty resulting from a firm's information advantage over consumers. This theory proposes that firms whose products are of superior to average quality will send credible signals which consumers will then use to distinguish firms with high-quality products (Boulding and Kirmani, 1993). Signals disseminate information through both tacit and explicit messages that disclose information on a firm's quality, future behaviour, intentions, values and capabilities (Bergen et al., 1992; Kirmani and Rao, 2000). Signalling would be an efficient method of solving classification problems on international markets, were it profitable to high quality firms but not to low-quality firms (Boulding and Kirmani, 1993). It is undoubtedly a useful theory to understand a "firms reputation of a COO" as a signal that is used to convey information on foreign firms to consumers (Bilkey and Nes, 1982; Ahmed et al., 2004; Teas and Agarwal, 2000). In situations where quality is unobservable, the positive impact of a good reputation increases the probability of trusting in foreign firms and purchasing their products (Anderson and Weitz, 1992). Thus, low-reputation firms may try to hide their 
COO and signal other attributes (Thakor and Kohli, 1996).

Nevertheless, a careful literature review reveals a lack of research about a cue linked to $\mathrm{COO}$ effect that works as a signal of quality and reflects the consumer's perception of the capability of firms associated to a certain COO. Few empirical studies have investigated the effectiveness of a $\mathrm{COO}$ reputation as a signal of quality (Hong and Wyer, 1990; Chisik, 2003). Indeed, there is no commonly established definition of what $\mathrm{COO}$ reputation actually means and several suggestions exist in the literature. A study carried out by Roth and Romeo (1992) stressed that the COO concept is a reflection of the prestige and recognition of a country regarding its capability to produce and trade a product. Our study tries to empirically test the consequences of the concept of "firms reputation of a COO" as a signal of quality that reflect firm or manufacturer's capabilities to offer and maintain specific attributes in a particular product category. According to Amine and Shin (2002), a lack of country information will often blind a consumer to a product's real quality or attributes. This fact added to stereotypical information related to the origin of the products may determine consumer information processes and override previous negative information stored in the memory. This is especially true in the case of consumer goods such as automobiles (Das and DeLoach, 2006), where it is very difficult that consumers really know where an automobile is manufactured or assembled.

Thus, attending the concept of $\mathrm{COO}$ reputation as described in theoretical terms by Chisik (2003), our approach focuses on the operationalization of reputation of firms or manufacturers associated to a certain Country of Origin as a signal that reflects the perceived capabilities of the latter. Thus, we define firms' reputation of a $\mathrm{COO}$ in terms of a quality signal that reveals information on the quality of the goods produced by manufacturers or firms linked to a specific origin. ${ }^{2)}$ Consumers have a reduced knowledge of information about foreign products quality and firms' behaviour. In this situation, consumers could use the "firms reputation of a COO" signal to infer information on the quality of the goods produced by manufacturers or firms linked to a specific origin. This signal may work as a summary construct with a direct effect on consumer attitudes and purchasing behaviour (Han, 1989).

\subsection{Consumer ethnocentrism}

Consumer ethnocentrism is a variable that partially explains the preference for a product based on its origin. The concept of ethnocentrism

2) "Firms reputation of a COO" implies consumer's perception of the capability of firms associated to a certain Country of Origin that usually is an association between country original address and it can disassociate the products and firms from their manufacturing place (Ahmed et al., 2004; Thakor and Kohli, 1996). 
emerges from the study of social events in terms of group interactions and interrelations. It has frequently been applied to social collectives, as an expression of human nature that looks at its identity, protection and group preservation. The group is the key reference to evaluating other aspects, such that ethnocentrism may therefore be conceived of as a way of preserving a group's culture, solidarity, cooperation, loyalty and survival (Caruana, 1996).

The definition of ethnocentrism was originally introduced by Sumner (1906): a view in which one's group is the center of everything, and all others are scaled and rated with reference to it.... each group nourishes its own superiority.... and looks with contempt on outsiders (p. 13). This perspective could be helpful to partially explain consumer purchasing behaviour. Consumers use their behaviour to differentiate themselves as members of a social collective (Jin et al. 2006). Consequently, consumers may feel a moral obligation to preserve the group's welfare. Shimp and Sharma (1987) define consumer ethnocentrism as a belief held by consumers on the appropriateness and indeed morality of purchasing foreign-made products (p. 280). Consumer ethnocentrism implies the normative belief that purchasing domestic products is more beneficial than purchasing imports (LuqueMartínez et al., 2000). In the literature on consumer behaviour, ethnocentrism is considered a component of attitude that is strongly linked to social and interracial factors (Ouellet, 2007).
Klein and Ettenson (1999) propose that an ethnocentric person believes that buying foreign products is unpatriotic and amoral, hurts the economy and can reduce employment levels (Shimp and Sharma, 1987; Javalgi et al., 2005: Ruyter et al., 1998). Ethnocentrism has a negative influence on the evaluation and purchasing intentions of consumers, although that may vary within cultures and between different country of origin products (Balabanis and Diamantopoulos, 2004; Grier et al., 2006). Granzin and Painter (2001) affirm that ethnocentrism causes consumer tendencies to protect their domestic economy and to help domestic workers with whom they identify. Consumers that display greater ethnocentrism stress the positive aspects of domestic products (Ruyter et al., 1998), and assume domestic products are superior to products imported from other countries, regions and cross-national associations (Kinra, 2006; Marín, 2005).

\subsection{Purchase intention of foreign products}

Research on predictors of purchasing behaviour has confirmed that consumers usually hold prior purchase intentions before they behave (Morrison, 1979; Lin and Chen, 2006; Grier et al., 2006: Agarwal and Teas, 2002). Purchase intention is the willingness of a consumer to buy a particular product (Doods et al., 1991; Grewal et al., 1998). Social psychology suggests that intentions should be the best predictor of 
individual behaviour, because purchase intentions reflect the consumer's own expression of purchase probability, independently of other relevant factors that could affect consumer behaviour and decisions (Young et al., 1998). Researchers have largely employed this variable as an antecedent of behaviour because it simplifies the measurement of behaviour, especially if we bear in mind the difficulties of observing the real purchasing process of each person (Chandon et al., 2005; Young et al., 1998; Newberry et al., 2003) ; nevertheless, any prediction of consumer behaviour based on purchase intentions is far from perfect. Several investigations have noted discrepancies between intentions and behaviours (Newberry et al., 2003; Bemmaor, 1995; Young et. al, 1998). Consumers in different countries give dissimilar priorities to the factors that affected their purchase intentions (Lee and Green, 1991). A more recent study by Chandon et al. (2005) measures consumer purchase intentions towards groceries, automobiles and laptops. Their conclusions provide evidence to suggest that the stronger the consumer purchase intention, the greater the probability of the consumer buying the products being evaluated.

\subsection{Firms reputation of a $\mathrm{COO}$ and ethnocentrism as antecedent of foreign products purchase intention}

Literature on $\mathrm{COO}$ proposes this cue as antecedent of the purchase intentions of foreign-made products and domestic products (Marín, 2005). Al-Sulaiti and Baker (1998) point out that the origin of the products ought to be included when the unit of analysis involves understanding the consumer buying behaviour process because the preferences, evaluations and purchase intentions of consumers are influenced by firms reputation of a $\mathrm{COO}$. A preceding investigation done by Yaprak (1978) explores Turkey consumer evaluation about automobiles, cameras and calculators from Germany, Japan and Italy, his results show that both general country and product attributes were statistically significant in affecting purchase intentions of products "made in" three different countries. Also, Ahmed et al. (1994) investigate the effects of country of origin on purchasing managers' product perceptions in terms of perceived quality and purchase value. Ahmed et al. (1994) indicated that newly industrialising countries were better evaluated as locations for the assembly of industrial products than as countries of design. For instance, South Korea was evaluated almost as well as France and Italy as a country of assembly. Respondents also rated Korea higher than Belgium as a country of assembly and almost as well as a country of design. Although brand name had a statistically significant impact on the perceived quality and purchase value of the product its explanatory power was much smaller than country of origin cue. On other hand, Diamantopoulos (1995) study establish 
that British and Germany consumer hold stereotypical images with regard to automobiles from different countries and these images affect the way in which the countries' products are evaluated before been purchased. As well Tse et al. (1996) results support that COO affects Chinese consumers' intention to purchase the products form Korea, China, Germany and Japan. Large body of research has developed over the past 40 years in an attempt to link $\mathrm{COO}$ in particular, "country image" with product evaluation and intention to purchase. However, research about the effects of $\mathrm{COO}$ reputation is scarcely. We suggest that consumers make stereotypical associations between products and countries based on their perceptions of a country's know how, prestige and reputation relative to the design, manufacturing, or branding of particular product. For example, some products are perceived as reputable and typically associated with a particular country of origin (e.g., vodka with Russia or cars with Germany) and this fact can stimulate their commercialization and acceptation in new markets. A good established reputation positively affects consumers' preference for certain products and increases the purchase intentions of products from this origin (O’Cass and Grace, 2003). Consequently:

H1: Firms reputation of a $\mathrm{COO}$ associated with foreign firms positively influences consumer purchase intentions towards foreign products.

Ethnocentrism might cause consumer tendencies to protect their domestic economy, to assist and even identify with domestic workers, to stress the positive aspects of domestic products, and to have a negative perception of imported products (Ruyter et al., 1998; Granzin and Painter). Consequently, consumers may feel a moral obligation to reject foreign products. Klein and Ettenson (1999) argued that an ethnocentric person believes that buying foreign products hurts the economy and can reduce national employment levels (Shimp and Sharma, 1987; Javalgi et al., 2005). Literature on ethnocentrism proposes this concept as antecedent of the purchase intentions of foreign made products and domestic products (Marín, 2005). Klein et al. (1998) state that the concept of ethnocentrism ought to be included when the unit of analysis involves understanding the consumer buying behaviour process, since studies of consumer ethnocentrism have generally found that ethnocentric consumers tend to avoid buying products from any foreign country (Suh and Kwon, 2002; Shimp and Sharma, 1987: Granzin and Painter, 2001; Ang et al., 2004: Sharma et al., 1995). The preferences, evaluations and purchase intentions of such consumers are influenced by consumer ethnocentrism. For example, Shimp and Sharma (1987) find that the ethnocentrism of American consumers is inversely related to their intentions to buy 
foreign-made automobiles. Subsequent studies with Portuguese and Korean consumers corroborate the fact that ethnocentrism increases the rejection of foreign products and enhances the purchase intentions towards domestic products (Granzin and Painter, 2001: Suh and Kwon, 2002). Recent research on consumer ethnocentrism in Spain shows that consumers prefer to purchase domestic products rather than foreign imports as a consequence of their ethnocentrism (Marín, 2005); a point which may be expressed by the following hypothesis:

H2: Consumer ethnocentrism negatively influences consumer purchase intentions towards foreign products.

\section{Method}

\subsection{Country-of-origin and product category selection}

Purchasing an automobile implies a high level of expenditure and consumers spend more time and money looking for additional information to evaluate this product than they spend on purchasing other products (Murphy, 1986). Consumers are more sensitive to country-oforigin when evaluating products with a symbolic status (automobiles), than for goods that are more frequently purchased (Hamzaoui and Merunka, 2006). The automobile is an important durable product in the economic and social life of developed countries. Vehicle registrations have increased over recent years in Spain, reaching rates that are comparable to those in more developed European countries (ANFAC, 2007). Accompanying this rise in vehicle registrations, between 2000-2007, the average percentile growth of non-European vehicles registered in Spain has also increased (13\%), of which 31,6\% correspond to Asian vehicles (DGT, 2008). Due to the global financial crisis and recent automotive industry crisis, new passenger car registrations in Spain market decreased 28\% compared to the same period last year. However, the average percentile growth of Korean automobiles registered in Spain has increased considerably (10\%), (DGT 2000-2008). Korean automotive industries are becoming more competitive. Last year automobile manufacturers from this origin sold 92,456 automobiles in Spain, which represents 5.7\% of the national market share. Their market share has almost doubled over the last years (from $3.7 \%$ in 2002) (DGT, 2002-2008). A pre-test with 30 respondents also helped us to know if the final statements were not ambiguous and were understood. Previously we evaluated consumers' perception about automobiles and we can say that Spanish consumers noticeably distinguish Korean automobile from Japanese, American and European automobile brands, which are perceived with a better reputation for producing 
high-quality products (Javalgi et al. 2005; Nagashima, 1970). Nevertheless and before consumers evaluated firms reputation of a $\mathrm{COO}$, the Korean automobile brands were mentioned to ensure that consumers really know which they are evaluating.

\subsection{Data Collection}

The universe is Spanish automobile owners of a passenger automobile. The data were collected from individuals who had to be the owners and users of a passenger automobile at the time of the interview. A total of 350 questionnaires were personally administered, though a first filter question concerning to previous experience about buying a car by the interviewed person caused some persons who were willing to answer have to be discarded. Lastly, only 202 questioners were usable resulting in an acceptable response rate of $57.7 \%$. This study employs simple random sampling. For data collection and questionnaire distribution, personal interviews are adopted. The demographic and socio-economic profile of the respondents of the sample is as follows: $63.9 \%$ of the subjects were male and $36.1 \%$ female. Respondent age groups were as follows: $54.4 \%$ from 18 to 35 years old, $36.6 \%$ from 36 to 55 and 9\% more than 56 years old. The monthly income ranged from below $€ 1200$ to over $5000 €$, being $41.9 \%$ under $€ 1200$, $40.7 \%$ of which lay between $€ 1201-€ 2400$; $14,3 \%$ between $€ 2401-€ 5000$, and $3.1 \%$ over
$5000 €$. Their household structures comprised couples with children (40.7\%), single people living alone $(33.7 \%)$, couples without children (20.6\%) and a small percentage of single parents with children $(5 \%)$. Finally, the most common professions in the sample were employees (65.6\%) and students (13.9\%). The profile of our sample is similar to automobile user profile established by the DGT (2007) (66.7\% of the drivers are male and $30 \%$ are from 25 to 34 years old).

\subsection{Measurements}

The Appendix records the items used in this study to measure each variable. In order to assure the content validity of the measurement scales, most relevant previous studies were reviewed and used as a reference that had previously applied the variables under study 'firms reputation of a COO', 'ethnocentrism' and 'purchase intentions'. The variables were measured by scales, which consisted of 5-point Likert questions anchored by strongly disagree with to strongly agree with. In order to measure ethnocentrism, reference was made to research by Shimp and Sharma (1987), Nijssen and Douglas (2004), Ettenson and Klein (2005), all of which coincide in their use of the "Consumer Ethnocentrism Tendencies Scale" (CETSCALE), designed by Shimp and Sharma in 1987. This scale consists of 17 items which were validated in several contexts such as the 
USA, France, Japan, Germany (Netemeyer et al., 1991), Turkey (Kaynak and Kara, 2002) and Spain (Luque-Martinez et al., 2000). The interchangeability of the CETSCALE indicators (Nijssen and Douglas, 2004; Luque- Martinez et al., 2000) allows researchers to employ fewer indicators to measure this variable (Ettenson and Klein, 2005; Russell and Russell, 2006; Reardon et al., 2005). The firms reputation of a COO was measured mainly by items drawn from the work of Doney and Cannon, (1997), Kaynak and Kara (2002) and Yasin et al. (2007). The items used to measure purchase intentions were formulated especially on the basis of works by Ettenson and Klein (2005), Dodds et al. (1991) and Agarwal and Teas (2002). In addition, the final section of the questionnaire collected personal demographic and socio-economic information, using scales for age, household structure, income, profession, education and gender.

\section{Results}

After a preliminary univariant and bivariant analysis that did not reveal significant anomalies in the data, the initial scales of firms reputation of a $\mathrm{COO}$, ethnocentrism and purchase intention were refined to achieve unidimensional, reliable and valid scales. The exploratory factor analysis was conducted to observe the unidimensionality of the latent variable measurements. Then, we employ the Harman's single-factor test which is one of the most widely employed techniques used by researchers to address the issue of common method variance (Andersson and Bateman, 1997; Organ and Greene, 1981). Attending Podsakoff and Organ (1986) and Podsakoff et al. (2003), we loaded all variables in our study into an exploratory factor analysis and examined the unrotated factor solution to determine the number of factors that are necessary to account for the variance in the variables. The first factor explained only the $26.4 \%$ of the data variance, which show that the findings presented can not be attributed to common method bias. Also, as recent researchers have suggested the confirmatory factor analysis (CFA) is a more sophisticated test of the hypothesis that a single-factor can account for all the variance data (Iverson and Maguire, 2000; Korsgaard and Roberson, 1995; Mossholder et al., 1998). In this line, our results show that the model fits worse in the case of single-factor analysis $\left[x^{2}=2123 \quad(\mathrm{p}=0.0) ; \quad \mathrm{RMSEA}=0.32 ; \quad \mathrm{NFI}=\right.$ 0.45; $\mathrm{CFI}=0.47 ; \mathrm{IFI}=0.47 ; \mathrm{RFI}=0.39 ; \mathrm{GFI}=$ $0.36]$ than in the case of three factor analysis $\left[\chi^{2}=531(p=0.00)\right.$; RMSEA $=0.06 ; \mathrm{NFI}=0.86$; $\mathrm{CFI}=0.90 ; \mathrm{IFI}=0.90 ; \mathrm{RFI}=0.85 ; \mathrm{GFI}=0.80]$.

A confirmatory factor analysis was performed using LISREL 8.7 to obtain the definitive scales and to test the convergent and discriminant validity of the measurement model (Jöreskog and Sörbom, 1993). The results of the adjusted 
model and the resulting variables that will be part of the global model estimation are shown in 〈Table 1〉. After validating the scales, the corresponding Cronbach alpha coefficients, composite reliability coefficients and extracted variances were calculated to confirm the reliability of the final scales (the result values were greater than 0.70, 0.60 and 0.50, respectively) (Bagozzi and Yi, 1988). The discriminant validity was assessed and fulfilled by verifying that the extracted variance associated with each construct was higher than the square correlations between the constructs (Table 1 and 2). After validating the measurement model, the structural equation analysis was conducted with the previously refined scales of latent variables to test the conceptual model. 〈Table 3〉 presents the assessment of the overall model fit and the

〈Table 1〉 Results of the adjusted confirmatory factor analysis

\begin{tabular}{|c|c|c|c|c|c|c|c|c|}
\hline \multirow[b]{2}{*}{ Latent Variable } & \multirow[b]{2}{*}{$\begin{array}{l}\text { Observed } \\
\text { variable }\end{array}$} & \multicolumn{3}{|c|}{ Lambda coefficients } & \multirow[b]{2}{*}{$\mathrm{R}^{2}$} & \multirow[b]{2}{*}{$a$} & \multirow[b]{2}{*}{$\begin{array}{l}\text { Composite } \\
\text { reliability }\end{array}$} & \multirow[b]{2}{*}{ AVE } \\
\hline & & $\lambda$ & $\begin{array}{l}\text { Measurement } \\
\text { error variance }\end{array}$ & $\mathrm{t}$ & & & & \\
\hline \multirow{5}{*}{$\begin{array}{c}\text { Firms reputation of } \\
\text { a } \mathrm{COO}\end{array}$} & V1 & 1.000 & 0.151 & - & 0.849 & \multirow{5}{*}{0.84} & \multirow{5}{*}{0.86} & \multirow{5}{*}{0.57} \\
\hline & $\mathrm{V} 2$ & 0.876 & 0.321 & 16.08 & 0.679 & & & \\
\hline & V3 & 0.547 & 0.719 & 8.137 & 0.281 & & & \\
\hline & V4 & 0.625 & 0.637 & 9.663 & 0.363 & & & \\
\hline & V5 & 0.765 & 0.466 & 12.97 & 0.534 & & & \\
\hline \multirow{6}{*}{ Purchase Intention } & V6 & 0.524 & 0.741 & 7.658 & 0.259 & \multirow{6}{*}{0.75} & \multirow{6}{*}{0.88} & \multirow{6}{*}{0.56} \\
\hline & V7 & 0.749 & 0.486 & 12.39 & 0.514 & & & \\
\hline & V8 & 0.826 & 0.382 & 14.49 & 0.617 & & & \\
\hline & V9 & 1.000 & 0.207 & 114 & 0.793 & & & \\
\hline & V10 & 0.708 & 0.536 & $\begin{array}{l}11.42 \\
12.22\end{array}$ & 0.464 & & & \\
\hline & V11 & 0.780 & 0.444 & & 0.556 & & & \\
\hline \multirow{3}{*}{ Ethnocentrism } & V12 & 0.890 & 0.150 & 24.84 & 0.850 & \multirow{3}{*}{0.80} & \multirow{3}{*}{0.90} & \multirow{3}{*}{0.76} \\
\hline & V13 & 0.848 & 0.352 & 16.88 & 0.648 & & & \\
\hline & V14 & 1.000 & 0.147 & - & 0.853 & & & \\
\hline
\end{tabular}

Goodness of fit index: $x^{2}=531(p=0.00) ;$ RMSEA $=0.06 ; \mathrm{NFI}=0.86 ; \mathrm{CFI}=0.90 ; \mathrm{IFI}=0.90 ; \mathrm{RFI}=0.85 ; \mathrm{GFI}=0.80$

$\langle$ Table 2〉 Correlation matrix between the latent variables

\begin{tabular}{cccc}
\hline & Purchase Intention & Firms reputation of a COO & Ethnocentrism \\
Purchase Intention & 1.00 & 1.000 & \\
Firms reputation of a COO & 0.432 & 0.008 & 1.000 \\
Ethnocentrism & -0.113 & \\
\hline
\end{tabular}


〈Table 3〉 Results of the final estimation of the model

\begin{tabular}{ccc}
\hline & Independent variable & \\
\hline Dependent variable & Firms reputation of a COO & Ethnocentrism \\
\hline Purchase Intention & $0.472(6.129) ; \mathrm{p}<0.05$ & $-0.120(-1.64) ; \mathrm{p}<0.10$ \\
\hline$x^{2}=227.04(\mathrm{p}=0.000) ;$ RMSEA $=0.05 ; \mathrm{NFI}=0.87 ; \mathrm{CFI}=0.92 ; \mathrm{IFI}=0.92 ; \mathrm{RFI}=0.88 ; \mathrm{GFI}=0.85$ \\
\hline
\end{tabular}

Significant at $p<0.05$ or $p<0.10$

supported hypothesis. According to the results, H1 is supported, since firms reputation of a COO was shown to significantly influences consumer purchase intentions $(\lambda=0.472, \mathrm{p}<$ 0.05). A opposite effect has ethnocentrism on consumer behaviour which has a negatively influence on purchase intention. This negative relationship slightly supports $\mathrm{H} 2 \quad(\lambda=-0.120$, $\mathrm{p}<0.10)$.

\section{Discussion}

This study highlights the importance of adopting a multidisciplinary perspective when examining the purchasing behaviour of consumers towards foreign products, which can help to overcome the shortcomings of economic and socio-psychological approaches. It leads us to conclude that not only are consumer purchase intentions influenced by objective criteria, but that psychological factors such as ethnocentrism. The results of this research empirically support the powerful influence of firms reputation of a $\mathrm{COO}$ in building consumer preferences in international markets, which demonstrates the essential role played by firms reputation of a COO seeking to do business in foreign markets. A final point is that a well reputation plays an outstanding role when relationships between consumers and firms from different countries are established. As expected, the perception of high quality products and reliable firm's capability are shown to be a necessary condition for developing consumer purchase intentions, which confirms that reputation of firms associated to a certain $\mathrm{COO}$ is an antecedent of consumer behaviour. Chryssochoidis et al. (2007) suggest that, in the case of ethnocentric consumers, the $\mathrm{COO}$ effect is activated automatically, namely that of the country a product originates in (country-specific), since in every domestic vs. foreign comparison the domestic product was evaluated overwhelmingly higher, with no variations caused by the category of product. In contrast to previous studies that suggest a strong direct and negative effect of ethnocentrism on purchase intentions (Suh and Kwon, 2002; Liu et al., 2006: Javalgi, 2005) in the case of Spain and related to Korean automobiles our results show that the relationship between ethnocentrism 
and purchase intentions could not be supported in 0.05 level. A plausible justification for this fact is found in previous studies by Klein et al. (1998) and Nijssen and Douglas (2004) who affirm that the unavailability of domestic alternatives, which is the case of Spanish automobiles, makes ethnocentric consumers willing to accept the purchase of foreign-made products. Moreover and consistent with our findings, prior research suggests that ethnocentrism may be more closely related to consumer judgments and evaluation of a product than to consumer intentions (Ettenson and Klein, 2005; Good and Huddleston, 1995). One of the findings in a recent study by Balabanis and Diamantopoulos (2004) is that ethnocentrism is a better predictor of consumers' positive intention towards domestic products than their negative intentions towards products imported from specific countries. Another important justification is that high ethnocentric consumers would be willing to buy imported products if they considered that those products were prestigious, which would make their purchase worthwhile (Klein et al., 1998). This aspect is covered by including firms reputation of a $\mathrm{COO}$, which implies that the prestige of Korean automobile firms is a more important factor for Spanish consumer than their ethnocentrism when considering to buy an automobile.

The results of this research entail several implications for marketing managers of international businesses. Literature on industrial economics and internationalisation has recognised the dilemma faced by organisations when they have to decide between internationalisation or adaptation and expansion in the domestic market. Therefore, firms and international trade organisations should pay attention to factors that can affect their competitiveness in international and domestic markets. Furthermore, the automotive sector operates in a global market and in order to avoid a decrease in consumer purchase intention and firm's sells and profits, firms competing abroad should consider whether consumers perceive their origin and how is the reputation associated to it. Foreign firms with good reputations have a competitive advantage to position their products in foreign markets because reputation can be an effective signal of quality if consumers believe firms will accomplish their responsibilities, promises and whatever else is expected of them (Singh and Sirdeshmukh, 2000). In addition, COO reputation could be transferred across firms from the same country, thereby enhancing the credibility of suppliers (Ganesan, 1994; Doney and Canon, 1997). Reputation is a powerful instrument that firms can use to increase future profits and establish solid relationships. Overall, reputation can mitigate asymmetric information problems between consumers and the firm. Recent research in Spain shows that consumers prefer to purchase domestic products rather than foreign imports as an attempt to protect national economy in circumstances of economic crises (Marín, 2005). Therefore, when firms try entering to a new market, their products will 
require strong promotional support of the firm's $\mathrm{COO}$ reputation because consumers are reluctant to purchase, or consider, a product with which they are unfamiliar because are foreign (Johansson et al., 1994). More important, our results suggest that the positive relationship between firms reputation of a $\mathrm{COO}$ and purchase intention is stronger than the negative relationship between ethnocentrism and purchase intentions. Furthermore, the automotive sector operates in a global market and in order to avoid a decrease in consumer purchase intention, international firms should avoid activating negative associations to their origin by different strategies: hiding their origin by promoting a global brand, establishing a join adventure with a local firm or mitigating negative effects of ethnocentrism by programs of social responsible that promote the development of the host country.

There are some limitations to this study, as well as opportunities for future research. Generalisation of the conclusions drawn from this work is restricted by the small sample size that is limited to a single geographic region. Moreover, the study only examines purchase intentions towards a specific product. Besides, it is a cross-sectional study; it would be interesting to design a longitudinal study that tracks survey participants over time to determine how relationships between variables change and if consumers finally buy a foreign made automobile even being ethnocentric. A further limitation derives from product selected for the study:
The automobile industry is a competitive sector where mergers and acquisitions are frequent; additionally, its products (automobiles) have progressively become more standardised and similar which make it difficult for consumers to differentiate automobiles by their origin and increase the propensity to mix up brands with country-of-origins. It is also possible to find a "halo" effect associated with a product image from a given country which extends to other product categories (Balabanis et al., 2002). Thus, this study has the limitation of not including control variables such as country of manufacturing, country of assembly, or country image. However, it is very difficult that consumers (and even the researcher) really know where an automobile is manufactured or assembled since globalization allows firms to design their products in a country, assemble them in another country and sold them using their country image if it is positive. There are several future lines of research to emerge from this study that might enrich the limited research that exists on this topic. It would be interesting to test the proposed model in other cultural contexts (for more than one type of product and in more than one country), in order to compare results. Moreover, it could be useful to include other antecedents and factors that influence consumer behaviour. Furthermore, future studies could be conducted to show how trust and animosity can influence consumer purchase intention. A future study could also 
test the moderating effect of some consumer personal characteristics and socioeconomic variables and should test the existence of a moderating effect of owning a foreign made product/brand (which may signal status and prestige) over the relationship between ethnocentrism and purchase intentions.

〈received: 2009. 04. 15〉 〈accepted: 2009. 06. 26〉

\section{References}

Agarwal, S. and Teas, R. K. (2002): "Crossnational applicability of a perceived quality model," Journal of Product \& Brand Management; 11:4, pp.213-236.

Agrawal, J. and Kamakura, W.A. (1999): "Country of origin: A competitive advantage?," International Journal of Research in Marketing, 16:4, pp. 255-267.

Ahmed, S.A., d'Astous, A. and El Adraoui, M. (1994): "Country-of origin effects on purchasing managers' product perceptions," Industrial Marketing Management, 23:4, pp. 323-32.

Ahmed, S.A. y d'Astous, A. (1996): "Country of Origin and Brand effects: A MultiDimensional and Multi-Attribute Study," Journal of International Consumer Marketing, 9:2, pp.93-115.

Ahmed, Z.U., Johnson, J.P., Yang, X., Fatt,
C.K., Teng, H. S., Boon, L.C. (2004): "Does country of origin matter for lowinvolvement products?," International Marketing Review, 21:1, pp. 102-120.

Al-Sulaiti, K. and Baker M.J. (1998): "Country of origin effects: a literature review," Marketing Intelligence \& Planning, 16:3, pp. 150 - 199.

Amine, S. L. and Shin, S.H. (2002): "A comparison of consumer nationality as a determinant of $\mathrm{COO}$ preferences," Multinational Business Review, 10:1, pp. 45 - 53.

Anderson, E. and Weitz, B. (1992): "The Use of Pledges to Build and Sustain Commitment in Distribution Channels," Journal of Marketing Research, 29:1, pp. 18-34.

Andersson, L. M., and Bateman, T. S. (1997): "Cynicism in the workplace: Some causes and effects". Journal of Organizational Behavior, 18, pp.449 - 469.

ANFAC (Spanish Automobile and Trucks manufacturers' Association (2007): "Memory 2007," http://www.anfac.com/global.htm Ang S.H., Jung K., Kau A.K., Leong S.M., Pornpitakpan C., Tan S.J. (2004): “Animosity towards economic giants: what the little guys think," Journal of Consumer Marketing, 21:2/3, pp. 190-207.

Bagozzi, R.P. and Yi, Y.(1988): "On the evaluation of structural equation models," Journal of the Academy of Marketing Science, $16: 1$, pp. $74-94$.

Balabanis, G. and Diamantopoulos, A. (2004): 
"Domestic Country Bias, Country-of- Origin Effects, and Consumer Ethnocentrism: a multidimensional unfolding approach," Academy of Marketing Science, 32:1, pp. 80-95. Balabanis, G. y Diamantopoulos, A. (2004): "Domestic Country Bias, Country-of-Origin Effects, and Consumer Ethnocentrism: a multidimensional unfolding approach," Academy of Marketing Science, 32:1, pp. 8095.

Balabanis, G., Mueller, R., Melewar, T.C. (2002) : "The values' lenses of country of origin images," International Marketing Review, 19:6, pp. 582-610.

Bemmaor, A. C. (1995): "Predicting behaviour from intention-to-buy measures: The parametric Case," Journal of Marketing Research, 32:2, pp. 176-191.

Bergen, M.; Dutta, S., Walker, O. (1992): "Agency Relationships in Marketing: A Review of the Implications," Journal of Marketing, 56: 3, pp. 1-24.

Bilkey, W.J. and Nes, E. (1982): "Country-oforigin effects on product evaluations," Journal of International Business Studies, 13:1, pp. 89-99.

Boulding, W. and Kirmani, A. (1993): "A consumerside experimental examination of signalling theory: Do consumers perceive warranties as signals of quality?," Journal of Consumer Research, 20:1, pp. 111-124.

Caruana, A. (1996): "The effects of dogmatism and social class variables on consumer ethnocentrism in Malta," Marketing Intelligence and Planning, 14:4, pp.39-44.

Chandon, P., Morwitz, V.G., Reinartz, W.J. (2005): "Do Intentions Really Predict Behaviour? Self-Generated Validity Effects in Survey Research," Journal of Marketing, 69: 2, pp. 1-14.

Chisik, R. (2003): "Export industry policy and reputational comparative advantage," Journal of International Economics, 59:2, pp. 423451.

Cordell, V.V. (1992): "Effects of Consumer Preferences for Foreign Sourced Products," Journal of International Business Studies, 23:2, pp. 251-269.

Chryssochoidis, G, Krystallis. A, Perreas. P (2007): "Ethnocentric beliefs and countryof-origin (COO) effect Impact of country, product and product attributes on Greek consumers' evaluation of food products," European Journal of Marketing, 41:11/12, 2007, pp. 1518-1544.

Das J. and DeLoach S.B. (2003): "Strategic trade policy in the presence of reputation spillovers," The Journal of International Trade \& Economic Development, 12:2, pp.101-116.

DGT (Spanish Government Department responsible for Traffic (2000-2008): "Definitive statists of vehicle registration, http://www.dgt.es/ estadisticas/estadisticas03.htm

Diamantopoulos, A., Schlegelmilch, B.B. and Preez, J.P. (1995): "Lessons for pan Eu- 
ropean marketing? The role of consumer preferences in fine-tuning the productmarket fit," International Marketing Review, 12:2, pp. 38-52.

Dodds, W. B., Monroe, K. B., Grewal, D. (1991): "Effects of Price, Brand, and Store Information on Buyers' Product Evaluations," Journal of Marketing Research, 28:3, pp. 307-319.

Doney, P.M. and Cannon, J.P. (1997): “An examination of the nature of trust in buyerseller relationships," Journal of Marketing, 61:2, pp. 35-51.

Ettenson, R. and Klein J.G. (2005): "The fallout from French nuclear testing in the South Pacific," International Marketing Review, 22:2, pp. 199-224.

Ganesan, S. (1994): "Determinants of longterm orientation in buyer-seller relationships," Journal of Marketing; 58, 2, pp. 1-19.

Good, L.K and Huddleston, P. (1995): "Ethnocentrism of Polish and Russian consumers: Are feelings and intentions related?" International Marketing Review, 12:5; pp. 35-44. Granzin, K.L. and Painter, J.J. (2001): "Motivational influences on buy domestic purchasing: Marketing management implications from a Study of Two Nations," Journal of International Marketing, 9:2, pp. 73-94.

Grewal, D., Monroe, K.B., Krishnan, R. (1998): "The effects of price comparison advertising on buyers' perceptions of acquisition Value, Transaction Value and Behavior
Intentions," Journal of Marketing, 62:2, pp. 46-59.

Grier, S.A., Brumbaugh, A.M., Thornton C.G. (2006): "Crossover Dreams: Consumer Responses to Ethnic-Oriented Products," Journal of Marketing, 70:2, pp. 35-51.

Häubl, G. (1996): “A cross-national investigation of the effects of country of origin and brand name on the evaluation of a new car” International Marketing Review, 13:5, pp. 76-97.

Hamzaoui, L. and Merunka, D. (2006): “The impact of country of design and country of manufacture on consumer perceptions of bi-national products quality: an empirical model based on the concept of fit," The Journal of Consumer Marketing, 23:3, pp. 145- 155.

Han, C.M. (1989): "Country image: halo or summary construct?," Journal of Marketing Research, 26:2, pp. 222-9.

Han, C.M. and Terpstra, V. (1988): "Countryof-origin effects for uni-national and binational products," Journal of International Business Studies, 19:2, pp.235-255.

Hong, S.T. and Wyer, R.S. (1990): "Determinants of Product Evaluation: Effects of the Time Interval Between Knowledge of a product's country of origin and information about its specific attributes," Journal of Consumer Research, 17: 3, pp. 277-288.

Iverson, R. D. and Maguire, C. (2000): "The relationship between job and life satisfaction: 
Evidence from a remote mining community”. Human Relations, 53, pp. 807-839.

Javalgi, R.G., Khare, V.P., Gross, A.C., Scherer. R.F. (2005): "An application of the consumer ethnocentrism model to French consumers," International Business Review, 14:3, pp.325-344.

Jin, Z., Chansarkar, B., Kondap, N.M. (2006) : "Brand origin in an emerging market: perceptions of Indian consumers," Asia Pacific Journal of Marketing and Logistics, 18:4, pp.283-302.

Johansson, J.K., Douglas, S.P., Nonaka, I. (1985): "Assessing the impact of country of origin on product evaluations: a new methodological perspective," Journal of Marketing Research, 22:4, pp. 388-96.

Jöreskog, K. G. and Sörbom, D. (1993) LISREL 8: structural equation modeling with the SIMPLIS command language (Chicago, IL: Scientific Software International).

Kaynak, E. and Kara, A. (2002): "Consumer perceptions of foreign products: An analysis of product-country images and ethnocentrism," European Journal of Marketing, 36:7/8, pp. 928-949.

Kinra, N.(2006): "The effect of country of origin on foreign brand names in the Indian market," Marketing Intelligence and Planning, 24:1, pp.15-30.

Kirmani, A. and Rao, A.R (2000): "No pain, no gain: A critical review of the literature on signaling unobservable product quality,"
Journal of Marketing, 64:2, pp. 66-79.

Klein, J.G. and Ettenson R. (1999): "Consumer animosity and consumer ethnocentrism: An analysis of unique antecedent," Journal of International Consumer Marketing, 11:4, pp. 5-24.

Klein, J.G., Ettenson, R., Morris, M. (1998): "The animosity model of foreign product purchase: an empirical test in the People's Republic of China," Journal of Marketing, 62:1, pp. 89-100.

Korsgaard, M. A. and Roberson, L. (1995): "Procedural justice in performance evaluation -The role of instrumental and noninstrumental voice in performance appraisal discussions". Journal of Management, 21, pp. 657-669.

Lee, C. and Green, R.T. (1991): "CrossCultural Examination of the Fishbein Behavioral Intentions Model," Journal of International Business Studies, 22:2, pp. 289- 305.

Lee, H., Kim, C., Miller, J. (1992): “The relative effects of price, warranty, and country of origin on consumer product evaluations," Journal of Global Marketing, 6:1/2, pp.5580.

Lin, L.Y. and Chen, C.S. (2006): "The influence of the country-of-origin image, product knowledge and product involvement on consumer purchase decisions: an empirical study of insurance and catering services in Taiwan," Journal of Consumer Marketing, 23:5, pp. 248-265. 
Liu, F.; Murphy, J; Li, J; Liu X. (2006): "English and Chinese? The Role of Consumer Ethnocentrism and Country of Origin in Chinese Attitudes towards Store Signs," Australasian Marketing Journal, 14:2, pp. 5-16.

Luque-Martínez, T., Ibáñez-Zapata J.A., BarrioGarcia, S. (2000): "Consumer ethnocentrism measurement: An assessment of the reliability and validity of the CETSCALE in Spain," European Journal of Marketing, 34:11/12, 1353-1373.

Marín S.C. (2005) : El Origen Doméstico de los productos como ventaja competitiva: La Etnocentricidad del consumidor, $\mathrm{PhD}$ Dissertation, Universitat de València Servei de Publicacions (Spain).

Moon B.J. and Jain, S.C. (2002): "Consumer processing of foreign advertisements: roles of country-of-origin perceptions, consumer ethnocentrism, and country attitude," International Business Review, 11, pp. 117-138. Morrison, D.G. (1979): "Purchase Intentions and Purchase Behavior," Journal of Marketing, 43:2, pp. 65-74.

Mossholder, K. W.; Bennett, N.; Kemery, E. R.; Wesolowski, M. A. (1998): "Relationships between bases of power and work reactions: The mediational role of procedural justice”. Journal of Management, 24, pp. 533-552.

Murphy, P. E. (1986): “Classifying Products Strategically," Journal of Marketing, 50:3, pp.24-42.

Nagashima, A. (1970): “A Comparison of Japanese and U.S. Attitudes Toward Foreign Products," Journal of Marketing, 34:1, pp. 6874 .

Netemeyer, R. G., Durvasula, S., Lichtenstein, D. R. (1991): "A cross-national assessment of the reliability and validity of the CETSCALE". Journal of Marketing Research, 28:3, 320-327.

Newberry, C.R., Klemz, B.R., Boshoff, C. (2003): "Managerial implications of predicting purchase behavior from purchase intentions: a retail patronage case study," The Journal of Services Marketing, 17:6/7, pp. 609-618. Nijssen, E.J. and Douglas S.P., (2004): "Examining the animosity model in a country with a high level of foreign trade," International Journal of Research in Marketing, 21:1, pp. 23-38.

O'Cass, A. and Grace, D. (2003): "An exploratory perspective of service brand associations," The Journal of Services Marketing, 17:4/5, pp. 452-475.

Okechuku, C. (1994): "The importance of product country of origin: a conjoint analysis of the United States, Canada, Germany, and The Netherlands," European Journal of Marketing, 28:4, pp.5-19.

Organ, D. W. and Greene C. N. (1981): "The effects of formalization on professional involvement: A compensatory process approach”. Administrative Science Quarterly, 
26, pp. $237-252$.

Otnes, C.; Lowrey, T.M.; Shrum L.J. (1997):

"Toward an Understanding of Consumer Ambivalence," Journal of Consumer Research, 24:1, pp. 80 - 93.

Ouellet, J.F. (2007): "Consumer Racism and Its Effects on Domestic Cross-Ethnic Product Purchase: An Empirical Test in the United States, Canada, and France," Journal of Marketing, 71:1, pp. 113-128.

Ozanne, J.L., Brucks, M.; Grewal, D. (1992), "A study of information search behavior during the categorization of new products," Journal of Consumer Research, 18, pp. 452-63.

Podsakoff, P.M.; MacKenzie, S.B.; Lee J.Y.; Podsakoff, N.P. (2003): Common Method Biases in Behavioral Research: A Critical Review of the Literature and Recommended Remedies, Journal of Applied Psychology, 88:5, pp. $879-903$

Podsakoff, P. M. and Organ, D. W. (1986): "Self-reports in organizational research: Problems and prospects". Journal of Management, 12, pp. $69-82$.

Reardon, J., Miller, C., Vida, I., Kim, I. (2005): "The effects of ethnocentrism and economic development on the formation of brand and ad attitudes in transitional economies," European Journal of Marketing, 39:7/8, pp. 737-754.

Roth, M.S. and Romeo, J.B., (1992): "Matching product category and country image perceptions: a framework for managing COO effects," Journal of International Business Studies, 23:3, pp. 477 - 497.

Russell, D.W. and Russell, C.A. (2006): "Explicit and implicit catalysts of consumer resistance: The effects of animosity, cultural salience and country-of-origin on subsequent choice," International Journal of Research in Marketing, 23:3, pp. 321-331.

Ruyter, K., Birgelen, M., Wetzels, M. (1998): "Consumer ethnocentrism in international services marketing," International Business Review, 7:2, pp.185-202.

Samiee, S. (1994): "Consumer evaluation of products in a global market," Journal of International Business Studies, 25:3, pp. 579-604.

Sharma, S., Shimp T., Shin J. (1995): "Consumer Etnocentrism: A test of antecedents and moderators," Journal of the Academy of Marketing Science, 23:1, pp 26-37.

Shimp, T. A. and Sharma, S. (1987): "Consumer Ethnocentrism: Construction and Validation of the CETSCALE," Journal of Marketing Research, 24:3 pp. 280-289.

Singh, J. and Sirdeshmukh, D. (2000): "Agency and Trust Mechanisms in Consumer Satisfaction and Loyalty Judgments," Journal of the Academy of Marketing Science, 28:1, pp. 150-167.

Suh, T. and Kwon, I.G. (2002): "Globalization and reluctant buyers," International Marketing Review, 19:6, pp. 663- 680. 
Sumner, G. W. (1906): Folkways: The Sociological Importance of Usages, Manners, Customs, Mores, and Morals, Ginn and Co., Nueva York, NY.

Tan, S.J., Lee, K.S., Lim G.H. (2001) : "Warranty and warrantor reputations as signals of hybrid product quality," European Journal of Marketing, 35: 1/2, pp. 110-132.

Teas, R. K. and Agarwal, S. (2000): "The effects of extrinsic product cues on consumer perceptions of quality, sacrifice and value," Journal of Academy of Marketing Science, 28:2, pp.278-290.

Thakor MV. and Kohli C.S. (1996): "Brand origin: conceptualization and review," Journal of Consumer Marketing, 13:3, pp. 27-42.

Thorelli, H.B., Lim, J., Ye, J. (1989): "Relative importance of country of origin, warranty and retail store image on product evaluations," International Marketing Review, 6: 1, 35-46.

Tse, D.K. and Gorn, G.J. (1993): "An experiment on the salience of country-of-origin in the era of global brands," Journal of International Marketing, 1:1, pp. 57-76.
Verlegh, W.P. (2007): "Home country bias in product evaluation: the complementary roles of economic and socio-psychological motives," Journal of International Business, 38, pp. 361-373

Vida, I. and Reardon J. (2008): "Domestic consumption: rational, affective or normative choice?," Journal of Consumer Marketing, 25:1, pp.34-44.

Wright, P.L. (1975), "Consumer choice strategies: simplifying vs. optimizing," Journal of Marketing Research, 11, pp. 60-67.

Yaprak, A. (1978): "Formulating a multinational marketing strategy: a deductive crossnational consumer behavior model," $\mathrm{PhD}$ Dissertation, Georgia State University.

Yasin, M.N., Noor, M.N., Mohamad, O. (2007): "Does image of country-of-origin matter to brand equity?," Journal of Product and Brand Management, 16:1, pp. 38-48.

Young, M.R., DeSarbo, W.S., Morwitz, V.G. (1998): "The Stochastic modeling of purchase intentions and behavior," Management Science, 44: 2, pp. 188-202. 


\section{〈Appendix〉}

Variable description, statistical properties and their referenced authors

\begin{tabular}{|c|c|c|}
\hline Variable & Cod & Item description \\
\hline \multirow{5}{*}{$\begin{array}{l}\text { Firms reputation of } \\
\text { a } \mathrm{COO}\end{array}$} & V1 & Thinks that $\mathrm{COO}$ firms/brands possess a distinguished brand image. \\
\hline & V2 & Believes that COO firms/brands are prestigious. \\
\hline & $\mathrm{V} 3$ & Holds the conviction that COO firms/brands are well recognized. \\
\hline & $\mathrm{V} 4$ & Believes that COO firms/brands are frequently mentioned in the media. \\
\hline & V5 & $\begin{array}{l}\text { Holds the conviction that } \mathrm{COO} \text { firms/brands have a better reputation than } \\
\text { others }\end{array}$ \\
\hline \multirow{6}{*}{ Ethnocentrism } & V6 & Purchases domestic products instead of imports. \\
\hline & V7 & Feels obliged to avoid purchasing foreign-made products \\
\hline & V8 & $\begin{array}{l}\text { Believes that purchasing foreign products means other countries will get } \\
\text { rich off us }\end{array}$ \\
\hline & V9 & $\begin{array}{l}\text { Believes that purchasing foreign products hurts the domestic economy and } \\
\text { causes unemployment. }\end{array}$ \\
\hline & V10 & $\begin{array}{l}\text { Expresses a preference for domestic products despite any long-term cost } \\
\text { implications }\end{array}$ \\
\hline & V11 & Purchases foreign products only if domestic alternatives are unavailable. \\
\hline \multirow{3}{*}{$\begin{array}{l}\text { Purchase } \\
\text { Intention }\end{array}$} & V12 & A probability of buying $\mathrm{x}$ product. \\
\hline & V13 & To accept the idea of buying. \\
\hline & V14 & Willingness to buy. \\
\hline
\end{tabular}

